\title{
Improving Health Care Delivery through Islamization of Medical practice
}

Mohammad Yousuf Rathor ${ }^{1}$ and Azarisman SM Shah ${ }^{2}$

${ }^{1,2}$ Dept. of Internal Medicine, Faculty of Medicine International Islamic University Malaysia

\begin{abstract}
Advances in modern science and technology have not only reduced mortality from communicable diseases but increased physical comfort, life expectancy and quality of life. However its advances have generated changes in the moral values and basic philosophies of mankind, a bi-product being loss of faith in religion as a partner in healing. This has resulted in changes in lifestyle, moral degradation, laxity in sexual behaviours, and disrupting social values. New diseases caused by negative lifestyles such as sexual promiscuity, alcoholism, illicit drug use and smoking, take the greatest toll in terms of deaths and disability among young people. As a consequence, relevant international organizations have supported more novel approaches to health promotion.Good health is the basic requirement of every human being and one of the greatest blessings of ALLAH (SWT) on mankind. The Islamic way of life is a system of divine principles sent by Allah swt through revelation on Prophet Muhammad (saw) which covers physical, intellectual and spiritual needs of human life. It has many constructive ideas to offer in the field of health care and medical practice. It contains many teachings that urge nurturing of one's health and rejecting any behaviour, which are contradictory to health. Therefore by adopting an "Islamic way of life" we can promote behavioural change. Since Islam encourages adoption of modern technology and science in support of a greater good, we must understand it and adopt all that is good in it and propagate it in the spirit of Tawhid (Unity of God), for the benefit of all humanity. This paper seeks to analyse how medical professionals can promote healthy behaviour to specific target groups and public in general through teachings of Islam.
\end{abstract}

KEY WORDS: Health promotion, Islamization, Islamic lifestyle, Attitudes, Behaviour

\section{INTRODUCTION}

Religion, medicine, and healthcare have been intertwined in all population groups since the beginning of recorded history. ${ }^{1}$ All religions have a code of health conduct and humans through the ages have drawn on specific values from religious traditions in caring for the body. ${ }^{2}$ Living a happy and healthy life remains the objective and hope for the great majority of people and they pursue all possible means to attain it. Advances in modern science and technology in the past century have made life comfortable but in some instances its impact has been harmful. These technological advances have changed the focus of medicine from a caring, service oriented model to a technological, cure-oriented model. Over time Religion/spirituality $(\mathrm{R} / \mathrm{S})$ and health care got separated and shifted towards a secular code of ethics, relying on human reason. The ensuing changes in social environment, rising prosperity and changing lifestyles led to noncommunicable diseases like heart disease, stroke, diabetes, cancer and obesity which are a major

\section{Corresponding author:}

Mohammad Yousuf Rathor

Dept. of Internal Medicine,

Faculty of Medicine

International Islamic University Malaysia,

Jalan Sultan Ahmad Shah,

25200 Kuantan,

Pahang, Malaysia.

Email : rathor@iium.edu.my burden affecting poor and rich countries alike. Cross -sectional and prospective studies show that changing lifestyles are the leading cause of diseases in developed world. ${ }^{3-4}$ Many new diseases have also cropped up due to changes in the moral values, such as alcohol and drug abuse, promiscuity, nudity and adoption of an openly gay culture and lifestyle. Wild disco dancing and music, drugs and sex-oriented movies, magazines and commercial ads showing scantily dressed women in alluring poses, add fuel to the fire. Boys and girls, men and women, all are buried in its filth. Drug and alcohol abuse and excessive sexual indulgence have become more prevalent amongst adolescents and young adults. These events have led to conflict, loss of selfesteem, and disruption of family identities with increased divorce rates and number of unwed mothers. ${ }^{5}$

Good health depends on life style, environment, hygiene, quality of food, water, etc. Prevention of disease means forsaking unhealthy habits so that the impact of modifiable risk factors can be reduced. This has brought into focus the importance of health promotion which has been described as social and political action enhancing public awareness of health, fostering healthy lifestyle and creating conditions conducive to health. The First International Health Promotion Conference, held in Ottawa (1986), defined health promotion as "The process of enabling individuals and communities to increase control over the determinants of health and to 
improve their health" a theme that is holistically supported by Islamic values and injunctions. ${ }^{6}$ Subsequent international conferences and meetings have further clarified the relevance and meaning of key strategies in health promotion, including 'Healthy public policy' (Adelaide, 1988), and 'Supportive environments for health' (Sundsvall, 1991). The $4^{\text {th }}$ International conference on Health Promotion held in Jakarta (1997) reiterated the need for both the public and private sectors to promote health by pursuing policies and practices that avoid harming the health of individuals. Subsequently the WHO Regional Office for the Eastern Mediterranean in 2004, in conjunction with Islamic organizations convened a consultation on Islamic lifestyles and their impact on health development. This approach was reiterated by the Regional Consultative Committee at its $29^{\text {th }}$ meeting in 2005, which also recommended more effective consideration of the religious and cultural dimensions in the strategy.

Health promotion is the art of motivating people towards a state of optimal health and well-being. ${ }^{7}$ Its aim is to prevent society from undertaking highrisk behaviours that potentially cause a particular disease. A substantial body of literature and research has examined the associations between religiosity, health and lifestyle behaviours and revealed that $R / S$ is important in prevention of illness, promotion of wellbeing, and successful adaptation to life's changing circumstances. ${ }^{8-11}$ This paper seeks to analyze how health care professionals can motivate people towards a state of optimal health especially adolescents who account for $1 / 5$ th of the world's population through the teachings of Islam.

\section{Health Promotion through Islam}

The World Health Organisation (WHO) in 1948 defined health as "a state of complete physical, mental, and social wellbeing not merely the absence of disease or infirmity". ${ }^{12}$ The same principles have been the cornerstone of Islamic belief and healing since fourteen centuries. Religious teachings have a major impact on people's lifestyle. ${ }^{13}$ Until recently, assessing patients' R/S beliefs were viewed as superfluous and inappropriate. However the scenario has changed since the 1960 's, as many studies have shown that $\mathrm{R} / \mathrm{S}$ beliefs and activities are associated with better health outcome. ${ }^{14-16}$ In view of this evidence, R/S studies in health have progressively become a topic of interest for different academic professionals and researchers all over the world. ${ }^{17}$ Likewise, several distinguished hospitals and health care centres have incorporated it as complements to standard treatment regimens, and a number of medical and nursing schools have begun to incorporate it into their curriculums. 18,19

Religious practices have enormous potential for addressing today's societal problems as studies have shown that they have effectively worked as a coping and prevention strategy in health-related issues. ${ }^{14,20}$ Islam emphasizes health promotion and disease prevention, making it obligatory for all Muslims to dissuade practices that undermine individual and collective health. Islam, arguably, provides more rational fundamentals than many other belief systems when it comes to health. ${ }^{21}$ Addressing risky behaviours and implementing lifestyle changes rather than remedying specific diseases is more cost -effective because one modifiable risk factor cuts across several diseases. For example, smoking is one of the leading preventable causes of premature death, disease and disability around the world. ${ }^{22}$ It kills more than 6 million people worldwide annually and has been linked to disease of nearly all organs of the body. ${ }^{23}$ According to the Royal College of Physicians, nicotine is as addictive as heroin and cocaine. ${ }^{24}$ The adolescents who start smoking early, are more likely to become addicted to it. Moreover, they are more likely to use alcohol, drugs, and engage in unprotected sex. ${ }^{25}$ Therefore physicians should treat smoking and its nicotine addiction as a disease as it is preventable. ${ }^{26}$

In Malaysia an estimated five million people, or 22.8 per cent of the population, are smokers according to the National Health and Morbidity Survey (NHMS) and prevalence of smoking among Malaysian males remains high despite several population interventions over the past decade. ${ }^{27}$

Islam prohibits all that causes harm to self or to others. ALLAH' SWT says: "Do not kill yourselves; Allah is indeed merciful to you" ${ }^{28}$ and the Prophet (SAW) has said: "Whoever consumes poison to kill himself with it, then he will be consuming poison in the hellfire, and he will abide in it permanently and eternally'. ${ }^{29}$ Previously smoking was viewed as permissible but highly discouraged (makruh) in Islam, as it does not result in intoxication like alcohol or drugs such as marijuana. ${ }^{30,31}$ But more recently, many religious scholars consider it as prohibited (haram), due to its harmful effects. ${ }^{32}$

Drug abuse and alcohol consumption are biggest threat to human health around the world. Research has consistently demonstrated that they lead to accidents, health problems, and other social ills in the society. Alcohol consumption is the world's third largest risk factor for disease and disability, which Islam strictly forbids and in doing so it preserves people's lives, properties, honour and respect. Research has shown a negative relationship between religiosity and alcohol consumption and promiscuity. ${ }^{33-35}$

Allah swt says, "Satan's plan is (but) to excite enmity and hatred between you with intoxicants and gambling and hinder you from the remembrance of Allah and from prayer, will ye not then abstain?" ${ }^{36}$ Drugs such as marijuana, opium and cocaine, are in the prohibited category of "khamr" (intoxicants) due to their effect on the mind. The Prophet (SAW) has said, 'Every intoxicant is khamr, and every khamr is unlawful.' 37 
Promiscuity is another modifiable risk factor that translates into HIV/AIDS (Human immunodeficiency virus / Acquired immune-deficiency syndrome) and other sexually transmitted diseases. HIV infection accelerates the development of tuberculosis and its potential spread. In Malaysia infection with HIV and viral hepatitis were largely due to intravenous drug use $(71.1 \%)$, but now heterosexual transmission has increased to approximately $80 \%$ of the annual total by $2015 .{ }^{38}$ HIV and AIDS is the "natural product of modernity" and "sexual revolution" which requires intervention at all levels. A study has revealed that faith-based/religious organisations are potential devices in its prevention. ${ }^{39}$ Sex is considered a pious act in Islam, as long as it is done within the confines of a legal bond of matrimony, which ensures that both parties realise the full responsibility and obligations associated with the act itself. Islam encourages early marriage, as sex may affect human behaviour and health. The Prophet SAW used to encourage youth to get married early. On the contrary all sexual relations out of wedlock are forbidden in Islam. Allah swt says "And nor come nigh to adultery, for it is an indecent (deed) and an evil way" "and do not draw near to shameful deeds (whether) open or hidden" ${ }^{40}$ Furthermore, the Prophet (SAW) has said, "If fornication (adultery) becomes widespread, you should realise that new diseases will befall on the people, which their previous generation never suffered......' 41 It is therefore vital to educate the public especially youth on HIV/AIDS and factors that lead to it.

Obesity is another major modifiable risk factor that has increased in every segment of the population and is the major risk factor of heart disease, stroke and diabetes Type 2 . One in three adult Americans is overweight, another third is obese, and almost one-fifth of young people between 6 and 19 years of age is obese. It has also been linked to rising rates of childhood diabetes. ${ }^{42}$ Islam discourages over eating and thus by the principle of moderation, obesity can be avoided. Prophet Muhammad SAW has said overeating is the source of all disease and 'Most of the evil comes through full bellies'. ${ }^{43}$ In another saying He SAW has said, 'A Muslim is not a perfect Muslim who eats his fill and leaves his neighbours hungry.' Thus Islam has an important role in social integration and wellbeing of people. Allah (swt) qualifies it further, "Eat and drink, without going to excesses, For Allah does not like those who go to excess." 44

Islamic has placed great stress on the role of exercise in maintaining health. The Prophet SAW stressed regular physical activity and exercise horse riding, swimming, archery, wrestling and running; and he himself was a good rider and a good wrestler. He (SAW) is reported to have said: 'A strong believer is better and more beloved to Allah than the weak believer. ${ }^{45}$

Islam has highly emphasized on personal hygiene and purity. It permits the use of any substance, including alcohol based hand sanitizers, as a means of cleanliness thus contributing to better health. ${ }^{46}$ The Prophet (SAW) has said, "cleanliness is half of faith or the twin-half of faith. ${ }^{47}$

\section{Role of Muslim Physicians}

Lifestyle plays a major role in contributing to the global burden of disease 48,49 The issues of alcoholism, drug addiction, AIDS, etc. are lifestylerelated illnesses which require health promotion at every level-individual, families, communities, organizations, and policymaking bodies. Faith and religious beliefs are among the most influential factors affecting human behaviour. In general, religion's positive influences can be incorporated into a comprehensive strategy for it. Health care professionals have a major role in advocating and enabling it. Since time immemorial, they have been accorded the highest honour and appreciation in the society and their word bears greater weight in righteously guiding their patient's orientation. The medical consultation and examination provide important opportunities for health promotion through education and counselling.

Medical professional's especially Muslim physicians are in a position to dissuade behaviour that undermines individual and collective health such as sexual promiscuity, drug and alcohol abuse, and smoking despite they being within the sphere of patient autonomy. They must perceive themselves as being commissioned by Allah (swt) to reflect Islamic values in their daily encounters with patients and the public. Every Muslim is responsible in guiding others to the righteous way of life: "Ye are the best of peoples, evolved for mankind, enjoining what is right and forbidding what is wrong, and believing in Allah." ${ }^{50}$ Therefore enjoining of good and forbidding evil is an obligatory action 'fard', which should be followed by all Muslims. Their motivation to correct others should be out of sincere love and care for their brethren. The Prophet (SAW) has said, "None of you are truly believes until one loves for his brother what he loves for himself."

Besides Muslim professionals must identify opinion leaders, peers, and targeted media channels to diffuse awareness about various diseases and encourage seeking help when affected by such ailments. They must identify voluntary individuals such as Imams of Masjids and Madrasa teachers, train and educate them regarding various health related issues, who can then play a vital role in promoting social reforms due to their intimate contact within the community.

\section{CONCLUSION}

Despite the overwhelming global influence of Western ideas of secularism, religion persists and lies at the heart of most cultures. Health issues continue to intensify around the globe including Muslim society. ${ }^{52,53}$ Islam is a comprehensive guide 
to all aspects of life for the individual and the community. Contrary to western belief, Islamic concept of health and wellbeing is contemporaneous, pragmatic and cutting edge despite being 'formulated' more than 14 centuries ago. There is an urgent need to incorporate it in daily practice for disease prevention.

\section{REFERENCES}

1. H. G. Koenig, D. E. King, and V. B. Carson, "A history of religion, medicine, and healthcare," in Handbook of Religion and Health, pp. 15-34, Oxford University Press, New York, NY, USA, 2nd edition, 2012.

2. Koenig, Harold G "Religion and Medicine I: Historical Background and Reasons for Seperation" The International Journal of Psychiatry in Medicine (38: 3, 2001) 385-398

3. Zimmet P, Alberti KG, Shaw J. Global and societal implications of the diabetes epidemic. Nature 2001; 414: 782-7

4. Stampfer MJ, Hu FB, Manson JE, Rimm EB, Willett WC. Primary prevention of coronary heart disease in women through diet and lifestyle. N Engl J Med 2000; 343: 16-22.

5. The world health report 2006: working together for health. Geneva: WHO, 2006

6. Ottawa Charter for Health Promotion, 1986. Available at http://www.who.int/hpr/NPH/ docs/ ottawa_charter_hp.pdf

7. O'Donnell, M. P. Evolving definition of health promotion: what do you think? Am J Health Promot 2008. 23 (2): iv.

8. Booth J, Martin JE. Spiritual and religious factors in substance use, dependence, and recovery. In Handbook of Religion and Mental Health, ed. HG Koenig, 1998; 175 -200.

9. Jeffrey S. LevinHarold Y. Vanderpool. Religious Factors in Physical Health and the Prevention of Illness Prevention in human services 2008;9(2):41-64

10. Pargament, K. I., Magyar, G., \& Murray, N. The sacred and the search for significance: Religion as a unique process. Journal of Social Issues, 2005; 61: 665-87.

11. Jeff S. Levin and Harold Y. Vanderpool, "Is Frequent Religious Attendance Really Conducive to Better Health? Towards an Epidemiology of religion," Social Science Medicine. 1987; 24:589-600

12. WHO, "Constitution of WHO: principles", http://www.who.int/about/mission/en/.

13. Piedmont RL. Spiritual transcendence as a predictor of psychosocial outcome from an outpatient substance abuse program. Psychol Addict Behav. 2004; 18(3):213-22.

14. Koenig HG, McCullough ME, Larson DB. Handbook of religion and health. New York: Oxford University Press, 2001.

15. Hummer, R., Rogers, R., Nam, C., \& Ellison, C. Religious Involvement and US Adult Mortality. Demography 1999; 36: 27385.

16. Bensley RJ. Defining spiritual health: a review of the literature. J. Health Educ. 1991; 22 :
$287-90$

17. Moreira-Almeida A, Koenig HG, Lucchetti G. Clinical implications of spirituality to mental health: review of evidence and practical guidelines. Rev Bras Psiquiatr. 2014; 36(2):176 $-82$.

18. Barnard D, Dayringer R, Cassel CK. Toward a person-cantered medicine: religious studies in the medical curriculum. Acad. Med. 1995; 30 : $806-13$

19. Levin JS, Larson DB, Pulchalski CM. Religion and spirituality in medicine: research and education. J. Am. Med. Assoc. 1997; 9 : 792 93

20. Salem, M. O. (2006) Religion, Spirituality and Psychiatry. [Electronic Version].

21. Leeuw, Evelyne D "Islamic Health Promotion and Inter culturalization" Health Promotion International 1999; 14: 347-53

22. Ezzati M, Lopez AD, Rodgers A, Vander HS, Murray CJ: Selected major risk factors and global and regional burden of disease. Lancet 2002; 360:1347-60.

23. WHO 2015. WHO Tobacco Fact Sheet No 339. Updated July 2015. http://www.who.int/ mediacentre/factsheets/fs339/en/

24. Nicotine addiction in Britain; Royal College of Physicians 2000.

25. Willard and Schoenborn (1995) Helping Adolescents at Risk: Prevention of Multiple Problem Behaviours. https: / / books.google. $\mathrm{mu} /$ books?isbn $=1593852398$

26. BMJ 2000; 320: 397

27. Lim HK, Ghazali SM, Kee CC, et al. Epidemiology of smoking among Malaysian adult males: prevalence and associated factors. BMC Public Health. 2013; 7; 13:8.

28. Al-Qur'an; 4: 29

29. Related in Sahi -Bukhari and Muslim

30. Doi AR. Shariah: The Islamic law. London: Ta $\mathrm{Ha}, 1984 ; 2-84$.

31. Ghouri N, Atcha M, Sheikh A. Influence of Islam on smoking among Muslims. Br Med J 2006; 332:291-4

32. Gatrad AR Sheikh A. Medical ethics and Islam: principles and practice. Arch Dis Child 2001; 84:72-75

33. Abraham C, Sheeran P, Spears R, Abrams D. Health beliefs and the promotion of HIVpreventive intentions amongst teenagers: A Scottish perspective. Health Psychology, 1992; 11: 363-70.

34. Bree M. B, Pickworth W. B. Risk Factors Predicting Changes in Marijuana Involvement in Teenagers. General Psychiatry 2005; 62(3) 311-19.

35. Ahmad M. K, Harrison, J. Untapped Potential: Cultural Sensitivity-Islamic Persuasive Communication in Health Promotion Programs. Paper presented at the Global Communication and Development Conference, 2007; 16-21. Shanghai, China.

36. Al- Qur'an; 5:90

37. Related in Mishkat-ul-Masabih, 1939: 2-571

38. National Strategic Plan for ending Aids, 
Ministry of health Malaysia Putrajaya, 2015

39. Woldehanna, S., Ringhein, K., Murphy, C. et al. (2006). Faith in action: Examining the role of faith-based organizations in addressing HIV/ AIDS. Washington: Global Health Council.

40. Al-Qur'an; 17: 32 \& Al- Qur'an 6: 151

41. Related in Ibnu Majah

42. Katz, D.L. Childhood obesity trends in 2013:

Mind, matter, and message. Childhood Obesity 2013; 9(1): 1-2.

43. Related in Tirmidhi and Ibnu Majah

44. Al-Qur'an; 7: 31

45. Related in sahih-Muslim

46. Aboul-Enein, Basil H. "Health-Promoting Verses as Mentioned in the Holy Qur'an." J Relig

Health. 2014; 55: 821-29.

47. Related in sahih-Muslim

48. Easthope G. Lifestyle, health and disease. New York: Routledge, 2006

49. World Health Organization The world health report: reducing risks, promoting healthy life. Geneva: WHO, 2002

50. Al-Qur'an 3: 110.

51. Related in Sahih-Bukhari and Muslim

52. UNICEF. (2005). Investigating in the children of the Islamic world. New York: The United Nations children's Fund (UNICEF)

53. Leeuw E. D, Hussein A. A. Islamic health promotion and inter-culturalization. Health Promotion International, 1999; 14(4): 347-53. 